DOI: $10.15503 /$ jecs20152.268.282

\title{
REMARKS ON COMMUNES OF THE POLISH PEOPLE: THE CHARACTER OF ORGANIZATION, THE IDEOLOGY, THE MEANING
}

\author{
Piotr KuligowsKI \\ Faculty of History, Adam Mickiewicz University, \\ Umultowska 89D, 61-614 Poznań, Poland \\ E-mail address: piotr.kuligowski.1990@gmail.com
}

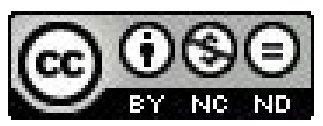

\section{ABSTRACT}

The aim of this paper is to rethink three important issues that refer to Communes of the Polish People's history. Firstly, it proposes a new understanding of organization frames, in which this group acted, using the Eric Hobsbawm's term labour sects. Secondly, the intention is to undermine the understanding of the ideological development of this organization through the prism of theoretical activity of Stanisław Worcell and Zenon Świętosławski. In this case it proposes to show Communes of the Polish People in the context of changing of Polish political vocabulary in the 1830s and 1840s using the Reinhardt Koselleck's term Sattelzeit. In this case the most durable achievement of Communes is invention of the term "Poland of the People" (Polska Ludowa). And thirdly, the article shows that references to Communes became extinct in the 1880s, at the time of the twilight of Romanticism.

Keywords: labour sects, Sattelzeit, socialism, StanisławWorcell, the Great Emigration, Zenon Świętosławski

Communes of the Polish People ${ }^{29}$, according to the literature the first Polish socialist group, do not arouse any discussions in Polish public debates nor in the humanities. Despite great significance of historical policy, this organization stayed totally forgotten. Although in my opinion it is reasonable to return to some themes with regard to Communes of the Polish People's history, because it can shed new light onto Polish history in the $19^{\text {th }}$ century in a wider sense, additionally, 2015 (the year of creating of this article) is and also the $180^{\text {th }}$ anniversary of emerging of the first Commune (after the split in Polish Democratic Society - Towwarzystwo Demokratyczne Polskie). Moreover, Gromady are also interesting because they allow researchers to observe the specificity of early socialist thought, created by people from periphery of the well-developed state.

In this article I want to rethink three important issues that refer to Communes of the Polish People's history. Firstly, I propose a new understanding of organiza-

29 In my text with 2012 I have translated Gromady Ludu Polskiego as "Clusters of the Polish People" (Kuligowski 2012). However, actually I worked on translation made by Peter Brock in his texts about Gromady Ludu Polskiego (Brock, 1954; Brock, 1977), because for me it seems to be more relevant. 
tion frames, in which this group acted. Therefore I claim that few threads in Communes of the Polish People's political thought suggest that the structure of this group had a quasi-anarchist character. Moreover, it has been proved that a useful category to a deeper understanding of this peculiar organization is Eric Hobsbaw$\mathrm{m}$ 's term labour sects. Secondly, my intention is to rethink the understanding of the ideological development of this organization through the prism of theoretical activity of Stanisław Worcell (first period) and Zenon Swiętosławski (second period), which is typical in existing historiography. In this case I propose to show Communes of the Polish People in the context of changing of Polish political vocabulary in the 1830s and 1840s using the Reinhardt Koselleck's term Sattelzeit. In this case the most durable achievement of Communes was the invention of the term "Poland of the People" (Polska Ludowa). Another thing I want to show is that the split in Polish Democratic Society and as the result the emergence of Communes of the Polish People did not necessarily show (as claimed by many researchers) the significant fracture in Polish political thought. Of course, the Communes of the Polish People introduced totally new threads to the Polish political life. On the other hand Polish socialist thinkers had already been functioning a few years before, so in my opinion indicating that the Communes introduced socialism to the Polish thought is imprecise. Thirdly, I indicate that the meaning of Communes is that it partially sets ways of thinking about political subjects into Polish ground. In other words, wide definition of historical agents for a long time paved the framework for reflections about that. In effect, in Polish leftist political thought concepts of different kinds of vanguards, popular in the West not only in Władimir Lenin's version, but also in different forms already in the $19^{\text {th }}$ century, was not very significant. Last but not least, in the article I show references to Communes as extinct in the 1880s, at the time of the twilight of Romanticism.

The majority of material sources in my consideration contains the monumental anthology of Communes texts - "The Polish People on the Emigration 18351846"30 (Lud Polski w emigracji 1835-1846), published by Z. Świętosławski (18111875) in 1854.

\section{ANARCHIST SECTARIANS}

Birth in the crisis period is the feature of every kind of deeper political thought. Without doubt in Polish history the period after the three partitions $(1772,1793$, 1795) and - in a longer time perspective - after the November Uprising (1830-31) can be interpreted as a crisis. At the turn of the $18^{\text {th }}$ and $19^{\text {th }}$ century a large country in the Mid East Europe ceased to exist, what was an unprecedented event in the modern Europe. Although the Napoleonic Times brought a short revival of the substitute of state (so-called "the Duchy of Warsaw"), in 1815 this short-lived bridgehead of the statehood had been already liquidated. Nonetheless, the certain elements of independence, like Poland's own constitution, survived. After the

30 Translations of titles and quotations with sources texts made by the author (unless otherwise noted). 
November Uprising (caused, among others, by the violations of the Constitution by the Tzar) even these remnants of political freedoms had been lost.

After the November Uprising thousands of its participants decided to leave the Polish grounds, we can recognise several waves of emigration - this phenomenon is well-known as the Great Emigration. Thousands of $e x$-soldiers settled in the UK and in France where they started to participate in public life of these countries. In consequence, many modern political concepts, for example ideas of democracy, human rights, socialism etc. appeared in Polish political thought very early in comparison with other countries of the region. In the 1830s, so in the time of ideological confusion and exploration, the issue of inventing new political subjects became visible for the democratic part of participants in the independence movement. In their opinion, the nobility (szlachta), despite its privileged position in society, failed to fulfil its task during Polish partitions (in the last quarter of the $18^{\text {th }}$ century) and during the November Uprising didn't assure the victory either. Under these circumstances the necessity of finding another stratum able to take the lead of struggles for independence seemed to be urgent.

Answers to this burning issue were attempted by the representatives of Polish Democratic Society, founded in 1832 (existed to 1862, but the peak of its activity and meaning occurred on the Spring of Nations). It was the first group in Europe and the second in the world, which used the term "democracy" in its name (Kalembka, 1971, p. 114). The members of this organization perceived themselves as "friends of the people" and preached a democratic program. Soon after the creation of the Polish Democratic Society, in December 1833, a ship "Marianne" arrived in the UK (Temkinowa, 1962, p. 7; Sikora, 1974, p. 7). On board there were former soldiers of peasant origin derived primarily from the Forth Regiment of Line Infantry (Czwarty Putk Piechoty Liniowej), who had fought in the battles of Olszynka Grochowska and of Ostrołęka during the last uprising. Some of them had even served in Napoleon's army (Jodko-Narkiewicz, 1904, p. 12; Sikora, 1974, p. 7). After the collapse of the November Uprising they were imprisoned in the Prussian stronghold Grudziąż. According to estimates by Adam Sikora, on average they were 30 years old. After their attempted revolt, the authorities decided to send them to the USA. As a result three ships set off for the USA, including 249 rebellious prisoners aboard the "Marianne". However, because of a storm, ships were forced to dock at harbours in the UK. Passengers from the "Marianne" decided to stay in Portsmouth. On $14^{\text {th }}$ February 1834 they obtained permission to stay (Temkinowa, 1962, p. 8; Sikora, 1974, p. 8-9).

The British government placed them in barracks, where a hospital for patients with cholera was located. Shortly thereafter these people were under the influence of Polish Democratic Society. Handwritten circulars of this group contain important information about the conditions of life of rebellious prisoners in the barracks. The Polish Democratic Society organized a public charity collection for them. Walls in the barracks were built with double boards and in winter it was hard to live there. Furthermore, in rooms there was no lighting and their inhabitants, due to the lack of a sufficient number of beds and bedding, had been sleeping on old Prussian coats (Okólniki, 1834-1836, card 10). Krzysztof Marchlewicz in his book 
about living conditions of Polish emigrants in the UK after the November Uprising claims that the British government provided for inhabitants of Portsmouth's barracks a special kind of grant, but the amount was small: one pound and one shilling per month (for comparison three pounds per month for senior officers) (Marchlewicz, 2008, p. 55-56).

Hard conditions of living can be understood not only in economic questions, but also in the context of migrants in Portsmouth snatched away from their familiar environment. This in turn facilitated the development of close relations inside the barracks. For example, in a building, in which they were situated, there was only one kitchen for more than two hundred people. As the result of similar incomes they had been eating similar food: bread, meat, salt and cabbage belonged to a typical menu of former Polish soldiers in Portsmouth (Marchlewicz, 2008, p. 202-203). This situation created a specific custom. For instance, different members of Communes held the children of others during baptism ceremonies (Lud Polski, 1854, p. 130). Also a special funeral ceremony was practiced within the group. The anthology of the Communes of the Polish People texts contains a few references about this case. For example Fabian Stępniewicz on his death bed was baptized at Communes hands. F. Stępniewicz and Jan Czarnecki after their death were escorted to the tomb and one anothers' representatives of Communes threw clods of earth on the coffins (Lud Polski, 1854, p. 44-45). The community of customs and the community of fates also intertwined in pathologies. Paydays, when former soldiers had been getting grants, was in Portsmouth's barracks traditionally the day of drinking alcohol (Marchlewicz 2008, p. 230).

I bring up all these details, because it seems to be important in order to rethink the character of Communes of the Polish People's organization but one more thing has to be explained. Generally, the $30^{\text {th }}$ October 1835 is the date of emerging of Communes of the Polish People, after the split inside Polish Democratic Society. The reason for this split was increasing ideological differences, primarily in the case of property, however as referring to the organizational character of Communes one premise plays an important role. During discussion inside the Polish Democratic Society between Portsmouth Section (123 members, inhabitants of barracks) and so-called "Central Section" radicals from Grudziąż argued that they were not "friends of the people". They tried to define themselves directly as "the people" (25th May 1835, in the circulars of the Polish Democratic Society) (Okólniki, 1834-1836, card 186). Soon after this violent discussion the first Commune, Grudziaż's Commune, was formed. The name of this Commune was associated with the Prussian stronghold, in which former soldiers were jailed, and between representatives of other political groups in the Great Emigration this name meant "hell" (Szpotański, 1907, p. 7). In turn on 14 ${ }^{\text {th }}$ March a former Section Jersey of Polish Democratic Society left the ranks of the organization and created the second Commune, Human Commune. This name was also shocking, because it aroused associations with the Humań slaughter (so-called Koliszczyzna, the massacre of Polish nobility and Jews by haidamaks in 1768) and was inscribed in a wider trend of justifying of carnage carried out by Ukrainian 
peasants on Polish nobility ${ }^{31}$. Thirdly, the more autonomist Commune, Praga's Commune, was given this name in the memory of slaughter in this Warsaw street, which was made by Russian soldiers during the November Uprising.

An assumption that the members of Communes were not "friends of the people", but that they were the people in the strict sense, who had already been expressed in the first manifesto of Communes (Lud Polski, 1854, p. 4) and was a recurring motif in the ideology of this group. It entailed conviction that the structure of Communes had not the artificial and political character. They were rather convinced that Communes were basic people's institutions, which they had reconstructed in exile. The representatives of this group claimed that the single Commune "consists of victims of unjust devices of human society, so as the representative of suffering of the Polish People is at the same time a natural representative of the needs of the people" (Lud Polski, 1854, p. 9). On behalf of the people they also rejected the official policy, for instance, the diplomacy. They wrote: the "Voice of the people should destroy diplomats actions. The people can act for themselves and by themselves (dlasiebieiprzezsiebie)" (Lud Polski, 1854, p. 49). These singular examples of apology for the people as such in coincidence with the importance of the policy of memory and their perception of themselves as the people implies consequences for imagination about the structure of Communes. The representatives of this group agreeably indicated that creating of new Communes did not require the approval of the existing Communes (Lud Polski, 1854, p. 84). Moreover, they were convinced that on the Polish soil peasants in villages also functioned in similar institutions (Lud Polski, 1854, p. 104). The Polish People on the Polish soil claimed members of the Communes in the UK - were living in Communes, so on the Great Emigration we must speak on their behalf (Lud Polski, 1854, p. 346-351). Generally, this question had very ideological character and the representatives of Communes were also conscious that they needed to rethink their own character - whether they were only political groups or maybe - in a wider sense - some sort of the organization of the Church or the Nation? (Lud Polski, 1854, p. 347). For these reasons I think that it is reasonable to interpret the organizational character of Communes as close to anarchism - (declaratively and in their understanding) non-hierarchical and decentralized. In other words, each Commune was treated by its participants as a kind of exhibitory microstructure, as an origin of a new world (Sepkowski, 1997, p. 134).

31 Generally this kind of the total promotion of bottom-up peasants activities against nobility was launched by Tadeusz Krępowiecki (1798-1847). In his speech on the occasion of the second anniversary of the November Uprising he paid attention to slaughters in Ukraine. He recalled the names of leaders of peasants uprising on the Ukrainian grounds like Iwan Gonta, Seweryn Nalewajko and - last but not least - "proud Khmelnytsky". This speech was shocking for auditors, because Tadeusz Krępowiecki's attitude towards these facts was positive and showed the conflict between peasants and nobilities in long-term perspective, denying solidaristic and idealized visions of Polish history (Krępowiecki, 1954, p. 148-162). Furthermore, his speech had gained recognition among French radicals (so-called Carbonari) and was published in the journal "La Tribune" and also as a separated brochure (Łukaszewicz, 1951, p. 227). After the break with Polish Democratic Society, T. Krępowiecki was an active member of Communes (to his ejecting in 1837) and probably inter alia by his influence texts of Communes were overflowing of the praise of people's terror. 
In this part of the article one more remark about the structure of Communes should be explained. Between historians there has been a discussion about what exactly Communes were. Two essential opinions can be noticed. The first group claims that Communes were radical religious groups, practically sects (Jodko-Narkiewicz, 1907, p. 60-61) or "penitential communes" (Zamoyski, 2015, p. 482). The second opinion is that Communes were just social and political groups (Szpotanski, 1907, p. 33-34; Brock, 1954, p. 566; Temkinowa, 1962, p. 97; Sikora, 1974). I have doubts about this division. My starting point in this matter is based on a general observation that the situation of the major part of the members of Communes was similar to the situation of British working class. Small amounts of government grants and low-salary jobs (for instance, Ambroży Lisiakowski, a member of a group, had been working in a laundry in London) (Lud Polski, 1854, 353) and fostered rapprochement and cooperation with the British working class. In this context using the E. Hobsbawm's term labour sects it seems to be relevant to conceptualize Communes of the Polish People. It means that it is possible to think about the syntheses of religious and political types of organizations.

The outstanding British historian claimed that early socialism played a role similar to different kinds of sects. He proved that in the first half of the $19^{\text {th }}$ century in Great Britain thousands of people turned to religious radicalism, which was an answer to fears caused by the Industrial Revolution (Hobsbawm, 1971, p. 127130). In his opinion, labour sects assimilated fast into the general pattern of radical democracy and as such were typical inter alia for migrant groups in London and harbour cities, in this case Portsmouth. E. Hobsbawm's conclusion is that these kinds of peculiar groups became extinct as the result of the development of industrial capitalism (Hobsbawm, 1971, p. 131, 148). To this last issue I will refer in the last part of the article.

\section{CONSCIOUS PRACTICE OF SATTELZEIT. COMMUNES AND THE DAWN OF MODERNITY}

In the existing historiography of Communes, whose important part was created most of all in the years 1945-1989, the ideology of this organization was often considered as utopian socialism or agrarian socialism ${ }^{32}$. However, I do not want to base my work on any of these categorizations. "Utopian socialism" of course refers to the periodization of the history of socialist thought proposed by Karl Marx and Friedrich Engels in The Communist Manifesto. In fact, this term was created by them in order to depreciate the heritage of socialist thinkers who acted before them. Whereas the

32 However, it is important to indicate that during last significant conference about Communes of the Polish People, in 1989, participants clearly were trying to overcome these schemes. For instance, Alina Barszczewska-Krupa argued that in Law of the Universal Church (Ustawy Kościola Powszechnego) - especially the future program was accepted by 49 members of Grudziąż Commune in 1844 - we can also find very realistic demands in the realm of public education or health care (Barszczewska-Krupa, 1989, p. 38-42). Whereas Zygmunt Najdowski admitted that the classical term "utopian socialism" can be understood not in an evaluative but in a descriptive sense, because it is based on historicism of social thought (Najdowski, 1989, p. 64-66). 
term "agrarian socialism", used by Polish historians during the Cold War period, had a pejorative connotation and generally had similar character to "utopian socialism". Thus both concepts were based on the conviction that the development of socialism is possible only in a specific stage of development of economic circumstances. Therefore, according to this point of view, in the 1830s and 1840s it was too early to formulate a fully socialist program. I want to think over this productivist point of view.

A typical interpretation of the history of the ideological development of the Commune is based on the indication that two essential phases can be distinguished.In the opinion of many historians the first phase was the period of ideological hegemony of S. Worcell (1799-1857) while the second phase - Z. Świętosławski. According to this point of view, the first few years after having emerged the Grudziąż's Commune meant the philosophical development of Polish early communism but however the 1840s for Communes was period of disintegration and growth of mystical moods. I try to rethink this distinction by wider contextualization of changes inside the ideology of Communes.

Firstly I want to present briefly ideological differences between these two thinkers. S. Worcell, who escaped from the Communes on $12^{\text {th }}$ April 1840 (Lud Polski, 1854, p. 203), made a substantial contribution in understanding the issue of property. As he claimed, the property is not a natural law. He preferred to interpret it as a social phenomenon and he thought that property as such keeps evolving. Actually, in S. Worcell's point of view, the form of property is contrary to the slogans of freedom, equality and fraternity - typical for the French Revolution - for this reason it should be changed (Worcell, 1854, p. 69-76). The fact, that S. Worcell's dissertation The Property (O wtasności) was published by Z. Świętosławski among other papers of Communes proves that it was accepted by all representatives of this organization during the gathering. It also shows that inside the Communes the most influential philosophical trends in the first half of the $19^{\text {th }}$ century were deeply discussed ${ }^{33}$. When Worcell left the Communes mystical elements had been gaining in importance.

In my opinion the useful category in this task is the term Sattelzeit, created by R. Koselleck. The outstanding historian of these ideas had been using that analytical category to indicate that in German history the period between 1750-1850 can be understood as the time of transition, when political concepts had been changing meaning and had been modernizing ${ }^{34}$. In other words, four dimensions of Sattelzeit

33 Especially often in the anthology of the Communes texts from 1854 Philippe Buonarroti appears, including a few speeches, created for his funeral (Lud Polski 1854, p. 137-145). But in addition to P. Buonarroti, the members of Grudziąż Communes in Portsmouth's barracks created a school, where they studied works of, for instance, Jean Jacques Rousseau, Philippe Buchez, Fr. Lamennais, Robert Owen and Pierre Joseph Proudhon. From Poland they knew Andrzej Frycz Modrzewski (Missalowa, 1951, p. 114-115). Let me add, that the ideas of the last were interpreted in a peculiar way. Seweryn Dziewicki (1810-1863) in his letter to Tadeusz Krępowiecki (12 ${ }^{\text {th }}$ March 1837), based on A. Frycz Modrzewski's works, criticized the nobility's practices of the ejection of peasants from their grounds. Remarks, formulated by S. Dziewicki, sound very similar to the condemnation of so-called "Enclosures" by Thomas More in the introduction to "Utopia" (by metaphor of ships, which swallowed people) (More 1993, p. 29). So S. Dziewicki's voice can be considered as a statement in a wider debate about the problem of "Enclosures" (see also: Bensaid 2010).

34 Even though I am aware of the fact that R. Koselleck had had a distance attitude to this term. As he said in one interview: "First of all, concerning Sattelzeit, I have to tell you that I invented the 
can be observed: temporalization (inserting of modern political and social concepts into a teleological framework of periods, phases, stages and the historical development), democratization (primarily in spheres of political language and political subject), ideologization (development of concepts in the direction of concretized ideology, adding suffix -ism to political terms) and politicization (traditional regimes broken by wars, revolutions, economic changes, meanings of words used as weapon by antagonistic classes, strata, movements) (Richter, 1996, p. 12-13). Modernity in the frame of Sattelzeit is characterized by obsessive interest in the future shown in the form of expectations, predictions, plans and utopias (Jordheim, 2012, p. 153).

Looking at the Communes ideology taking Sattelzeit into account makes the observation of radical transformation of political language possible. History of this group according to S. Worcell and Z. Świętosławski means neither more nor less than the transformation of political language in the direction of sacred language. Of course, the process of emerging of a Polish modern political language was totally different when compared to the analogical process in German history. However, without doubt the Great Emigration as such was the accelerator of this period of transition. But at the turn of the 1830s and 1840s an interesting phenomenon could be taken into account. That is to say, the 1830s is the period of the familarization with political languages of Western Europe. However, the long running emigration had been creating a deeper crisis in Polish political life. Under the circumstances of this crisis there was also a change in practicing of Sattelzeit. A lot of Polish political thinkers started to seek the solution of political problems in mystical moods. Early 1840s meant not only the dominance of $Z$. Świętosławski inside the Communes of Polish People. It was also the time of publicist activity of a group around another Polish Christian communist, Ludwik Królikowski (1799-1878), the publisher of “The Christ's Poland" (Polska Chrystusowa). To this trend we can also add Józef Ordęga (1802-1879) with his famous "Declaration of Leaving the Polish Democratic Society" (Deklaracja wystapienia z Towarzystwa Demokratycznego Polskiego), in which he used radical religious rhetoric (Ordęga 1981). Last but not least, in1842 there was created the Circle of God's Cause (Koło Spraw Bożej). In this group there were engaged famous persons, like, inter alia, Adam Mickiewicz (1798-1855), the forerunner of Polish Romanticism.

In this context I want to propose to interpret the change, which happened at this moment, as a shift in a political language, that means transformation from political language into a sacred language. Circumstances in which any radical left group did not exist in the Great Emigration ${ }^{35}$, and even though they were small,

term and used it for the first time in commercial advertise - ments created to promote the GG [Geschichtliche Grundbegriffe - PK] - to sell more issues. Although I am happy that succeeded in providing the lexicon with some money, I do not particularly like the term, mainly because it is very ambiguous. As you know, one of the meanings of Sattel refers to horses, to the equestrian world, and another refers to the situation experienced when one climbs to the top of a mountain and from there can contemplate a larger view. But in the end it does not allude in any specific way to the acceleration of time, which is the crucial aspect of the experience in the modern world" (original spelling) (Koselleck, Sebastian, Feuntes, 2006, p. 120).

35 Polish Democratic Society on $4^{\text {th }}$ December 1836 proclaimed so-called The Great Manifesto (Wielki Manifest). In this document representatives of the organization declared that they supported the ownership of the land and that they demanded the distribution of the land among the peasants. It meant to retreat from communist intuitions, which were presented in the earlier program from 
ephemeral and seeking alliance with bigger political groups, they caused the isolation of Communes. Therefore, perhaps the strong mystical communism of $\mathrm{Z}$. Świętosławski and his oneiric visions (like the text The Three Visions - Trzy Widzenia - published in L. Królikowski's "The Christ's Poland", but also in 1854 in the anthology of Communes text) (Świętosławski 1854a, p. 255-259) were the answer to some needs of the former soldiers in Portsmouth's barracks.

But in connection with the introduced term Sattelzeit one more remark is relevant. Namely, the conscious practice of the redefinition of political concepts seems to be an integral part of Communes theoretical activity. In "The Report of Preparatory Committee of Grudziąż's Commune" (February 1836, Sprawozdanie z Komissji Przygotowawczej Gromady Grudzią) they claimed that "speaking in the language of inflaming of a smoldering fire the committee considered as a duty" (przemawianie jezzykiem rozżażającym tlejący się ogień uważała Komissja za obowiazek)

(Lud Polski, 1854, p. 7).They were convinced, that they were living in the period of transition, in which "European peoples are thinking and are making terms of common happiness, this term can reach Poland and melt the frozen mass of the Polish people" (Lud Polski, 1854, p. 34). This type of statement also entailed the specific understanding of the Great Emigration as such. Members of Communes thought that staying in exile was serving to find the words of the truth (Lud Polski, 1854, p. 104). Perception of the political language inside the group was totally antagonistic - "in words from my mouth is sword", "our speech isn't speech of peace, but of war" (Lud Polski, 1854, p. 229-230).

Under these circumstances another dimension of conscious practicing of Sattelzeit was specific. The Communes, probably like all Polish political groups in exile, were seeking contacts with indigenous political and social organizations. It is obvious, that every group was trying to address its content primarily to similar organizations. For these reasons, the Communes of the Polish People were tending to cooperate with English "people's revolutionaries", mainly with Chartists, named by them as "the best friends of the Polish cause in England" (Lud Polski, 1854, p. 176-177). Taking my considerations into account I find interesting the idea of new meanings, which they attributed to correct the translations of political terms. Before the publication these articles, for example in the journal "The True Sun", there were detailed debates inside the Communes as to how to fully and deeply express their thoughts ( Lud Polski, 1854, p. 8). Especially of the protests, which were organized in connection with the arrival of Tsar Nicholas I of Russia, the members of Communes debated on how to translate correctly the term gminowtadztwo, the key-concept in the ideology of the organization. After discussion they decided to use the phrase "the will of the people at large", as the most relevant in their opinion (Lud Polski, 1854, p. 366).

However gminowtadztwo, though it was an important concept, was not created by the Communes. When practicing Sattelzeit and the belief in the acting power of political terms they invented another important concept, which had been used by a wide spectrum of Polish leftist groups for more than one hundred years after the dissolution of the Communes. Considering the people being a new political subject

1832 (so-called The Little Manifesto - Maty Manifest). 
recognised as "the base for the whole social structure" (Lud jest całej budowy społecznej podstawa) (Lud Polski, 1854, p. 169) they wanted to create a term which would connect the concept of the people and the image of Poland. As the result, the Communes constructed the concept of "Poland of the People" (Polska Ludowa), which meant the Polish vision of the republic of the people. Probably this concept was used for the first time $2^{\text {nd }}$ January 1837, in the context of abolition of the inheritance of lands property and other anti-nobles reform proposals (Lud Polski, 1854, p. 118). The concept of Poland of the People opened a new chapter in the Polish history. It was based on a specific vision of history, in which the nobleman exhausted the possibilities of development, and for this reason "Poland of nobilities" broke down twice, in 1795 and in 1830, after the third partition of Poland and after the collapse of the November Uprising (Lud Polski 1854, p. 125). In its general approach, the hazy and indeterminate project of Poland of the People derived from the ideological heritage of the French Revolution, because members of the Communes wanted to build this country under the flag of "Freedom, Equality and Fraternity". Their role, as emigrants and direct representatives of the people, had to rely on "acting in the presence of nations and showing, that we demand Poland of the People within the whole borders" (so in territorial shape before partitions) (Lud Polski 1854, p. 251).

In my opinion the invention of this term can be understood as the most durable achievement of the Communes of the Polish People. Moreover, Polska Ludowa is the evidence of some continuity of the ideology of a group because despite the change of the political language into a sacred language at the turn of the 1830s and 1840s, Poland of the People retained popularity. Eventually, the specific concept of the nation was inseparably associated with this term as a space of the violent social struggle, in which a new type of nation - "the people - nation" (lud-naród) must have been born. The ominous name of Human's Commune reminded of the necessity of bloodshed in order to resolve this issue (Brock, 1954, p. 573).

To sum up this part of the text: what is the meaning of the Communes in the history of Polish political thought? Generally, many historians claim that the moment of emerging of this group can be understood as the split between so-called "democratism" and socialism. In other words, in their opinion moderate leftism was still represented by Polish Democratic Society, whereas the Communes of the Polish People opened a totally new trend in Polish political thought (Jodko-Narkiewicz, 1907, p. 19, Brock 1954, p. 566). However, as indicated by Irena Koberdowa, in 1834 similar socialist principles had already been formulated by the Commune of the Polish Emigration (Gmina Emigracji Polskiej) in London (Koberdowa, 1989, p. 7). Her statement can be enhanced by a reminder that already during the November Uprising some thesis close to socialism had been trickling into Polish public life due to articles, published by L. Królikowski (Turowski, 1958, p. 26-32), who in turn came into contact with socialist instuitions (in Saint-Simonist's version) throughout Bohdan Jański (1807-1840) (Missalowa, 1951, p. 132). What is more, in 1834 Adam Gurowski (1805-1866) in his journal "The Future" (Przyszłośc) used the term sociabilite, which he tried to translate into Polish as follows towarzyszkość, socjalność and simultaneously he complained that an appropriate term does not exist in Polish ("Przyszłość" 1834, p. 18). 
In my opinion introducing the term "socialism" in Polish political thought was not the achievement of Communes of the Polish People. While examining the term "Poland of the People" I indicated the significant effect of theoretical activities of this organization was deepening the interest of the people as such, here and now, not after the transformation of this indeterminate group in a specific direction. Thus, they implicitly supported the bottom-up people's activities and tended to reconstruct their institutions and their language as the higher dimension of policy and of future world.

\section{FOUR POLISH PEOPLES AND THE TWILIGHT OF THE RADICAL ROMANTICISM}

Unfortunately, the Communes of the Polish People did not have an opportunity to comment the Galician Slaughter ${ }^{36}$. If they had had that chance, probably (like all of Polish political thinkers from all sides of political scene) they would have been shown to have had unequivocal criticism in relation to this kind of bloody peasant activity. On 22th March 1846, finding out about the Revolution in Cracow, they decided on dissolution, because the new Polish national government forbade separate actions (Lud Polski, 1854, p. 390-391). However, the meaning of the Communes of the Polish People was associated with the fact that they started to see the people as such, i.e. they did not preach slogans about the inclusion of the people in the presence of the nobility, as wanted by the representatives of Polish Democratic Society (Missalowa, 1951, p. 126). Predicated by them an apology for the people terror was only one of the layers of the consent to see all acts of peasants contestations as the political acts. Even eight years after the dismissal of the Communes, in 1854, Z. Swiętosławski in his introduction to the anthology of texts of Communes claimed that the peasant, who humbly bears a noble yoke, offends God (Świętosławski, 1854b, p. II).

The domination of this type of thinking in Polish leftist political thought coincides with the climax of popularity of the radical Romanticism and so-called "Romantic socialism" (Missalowa 1951, p. 112; Ciołkosz, Ciołkosz 1966). Therefore, besides adding a few important concepts to the Polish political language, the Communes also invented a specific kind of the organization, which survived until 1882. In 1856 in London Z. Świętosławski and Jan Kryński (1811-1890) (former members of the Communes of the Polish People) created the Revolutionary Commune of the Polish People. In turn in 1872 Walery Wróblewski (1836-1908), who was a commander in the January Uprising (1863-1864) and was a general in the Paris Commune, created the Association of the Polish People. And the last form of "the Polish People" functioned in Geneva in 1881-1882. The socialist Association of the Polish People, founded by Bolesław Limanowski (1835-1935), later one of the

36 The Galician Slaughter was the peasant uprising in the second half of February and March 1846 in the Austrian Partition (mainly around the town of Tarnów) against manorial property and oppression. At the same time Polish democrats began the Kraków Uprising and they promised the abolition of serfdom. So peasants turned their anger onto the revolutionaries, they killed hundreds of estate owners and their families. 
founders of Polish Socialist Party, in the proclamation of August 1881 discussed the meaning of "the people" as a social stratum in Polish leftist thought. As they claimed, the people are "the foundation of our existence", but till this moment (until 1881) any kind of political forces "failed to pick up [the Polish people - PK] the meaning of the active social force, so [the Polish people - PK] wakes up from sleep, demands shedding the yoke crushing his captive and desiring inner rebirth" (Odezwa, 1881). In the same proclamation it is possible to find the first signs of changes in Polish socialist thought, because the authors increasingly stressed the economic dimension of socialism rather than its community character. Thus the recurrence of "the Polish people" organizations became determinant of the epoch, and the twilight of this kind of group meant at the same time the fundamental change in Polish political thought.

In this context, the history of the Communes of the Polish People and the earlier incarnations of the group can be a contribution to the reflection about history of political thought in Central and Eastern Europe. As R. Koselleck claimed the continuity of transformations and gradual transformations exist in linguistic history, but political history is much more likely to have ruptures (Koselleck, Sebastian, Feuntes. 2006, p. 100). This reflection may be supplemented by the observation of Balázs Trencsényi, who claims that in history of Central and East Europe the state as such was non-indigenous and accidental, and that's why in Polish, Czech, Russian etc. political thought dominates the terminology, associated with cultural, linguistic and territorial communities, which are based on local experiences and were deeply rooted in the language (Trencsényi, 2004, p. 160-161). In this sense, theoretical works around the concept of "the people", which were made by the Communes of the Polish People and by later incarnations of this group, were sufficiently durable, because a characteristic feature of Polish left until 1945 was a wide definition of political subject, in which they located not only working class (or workers vanguard, like in Lenin's political thought and in different kind of Western socialist ideas, primarily inside the Second International), but also peasants, unemployed people, so-called "working intelligentsia", and during wars soldiers from leftist guerrilla groups as well. For these reasons, by using R. Koselleck's linguistic approach it is possible to observe the continuity between, for instance, the quasi-anarchist character of the Communes and the cooperative movement from the interwar period, whose representatives also tried to create the "community island" on the ocean of capitalism".

\section{CONCLUSION}

In the article I have been trying to use a few new categories (like E. Hobsbawm's term labour sect and R. Koselleck's methodological approach) to rethink the character of the organization, the ideology and the meaning of the Communes of the Polish People. I have established that in the first question it is possible to

37 Moreover, some researchers, for example Peter Brock, claimed that in ideology of Communes some cooperative elements existed (Brock 1977, p. 28). 
understand this group as an anarchist labour sect. In the second question, I indicated that the traditional division of the history of the Communes into the period of S. Worcell and period of Z. Świętosławski can be reinterpreted by the linguistic analysis. By applying this method I have been examining the origin of the mystical rhetoric of the Communes and I have proved that the original contribution of Communes was the insertion of the term "Poland of the People" into the Polish political language. And thirdly, I have outlined a wider meaning of the Communes against the background of the history of the Polish left and I have indicated that the specific feature of Polish leftist groups was a wide definition of political subjects.

Finally, I hope to trigger the discussion about the Communes of the People, which have been extinct after 1989. At least two research postulates can be formulated. Firstly, it would be interesting to compare the Communes with similar labour sects from other countries, with other national minorities in the early period of British capitalism. And secondly, I want to repeat the remark of I. Koberdowa, who wrote that the history of the Communes was often written by historians of the Great Emigrations, whilst it should be included in the history of Polish socialism, dating back to 1878 (Koberdowa ,1989, p. 7). Without doubt, the $180^{\text {th }}$ anniversary of the foundation of Grudziąż's Commune is the great occasion to examine the history of this group, using new research tools.

\section{SOURCES:}

Okólniki Towarzystwa Demokratycznego Polskiego 1834/1836 [Circulars of the Polish Democratic Society 1834/1836], sign. Cz21161; sign. Cz2104. The Kórnik Library of the Polish Academy of Sciences.

(1834). "Przyszłość" [The Future]. No. 1.

(1854). Lud polski w emigracji 1835-1846 [The Polish People in Exile 1835-1846], Świętosławski Z. (ed.). Jersey.

(1881). Odezwa Stowarzyszenia Socjalistycznego "Lud Polski” [Proclamation of the Socialist Association "the Polish People"], sign. ZHS-B81556. The Sejm Library.

Krępowiecki, T. (1954). Przemówienie wygłoszone w Paryżu 29 listopada 1832 r. w rocznicę rewolucji polskiej [Speech Given in Paris on 29th November 1832, in the Anniversary of the Polish Revolution]. In: W. Łukaszewicz (Ed.), Tadeusz Krępowiecki, żotnierz rewolucjonista [Tadeusz Krępowiecki, a Soldier Revolutionist] (pp. 148-162). Warszawa: Wydawnictwo Ministerstwa Obrony Narodowej.

More T. (1993). Utopia. Trans. by K. Abgarowicz, Smoczyński P. J. (Ed.). Lublin: „Daimonion”.

Ordęga, J. (1981). Deklaracja wystapienia z Towarzystwa Demokratycznego Polskiego [The Declaration of Departure from the Polish Democratic Society]. In: D. Kalbarczyk (Ed.), Wskrzesić Polskę- zbawić świat. Antologia polskiej myśli społeczno-radykalnej 1831-64 [To Resurrect Poland - to Rescue the World. The Anthology of Polish Socio-Radical Thought 1831-64]. Warszawa: Instytut Wydawniczy PAX.

Świętosławski, Z. (1854a). Trzy widzenia [The Three Visions]. In: Z. Świętosławski (Ed.), Lud polski w emigracji 1835-1846 [The Polish People in Exile 1835-1846] (pp. 255-259) . Jersey: Druk. Powszechna.

Świętosławski Z., (1854b). Do Narodu Polskiego [To the Polish Nation]. In: Z. Świętosławski (Ed.), Lud polski w emigracji 1835-1846 [The Polish People in Exile 1835-1846] (pp. I-IV). Jersey: Druk. Powszechna.

Worcell S., (1854). O własności [The Property]. In: Z. Świętosławski (Ed.), Lud polski w emigracji 18351846 [The Polish People in Exile 1835-1846]. Jersey: Druk. Powszechna. 


\section{BIBLIOGRAPHY:}

Barszczewska-Krupa, A. (1989). Wizje ustroju społecznego w polskiej myśli rewolucyjno-demokratycznej i socjalistycznej I połowy XIX w. (ze szczególnym uwzględnieniem Gromad Ludu Polskiego) [The Visions of the Social System in Polish Revolutionary-Democratic and Socialist Thought in the First Half of the 19th Century (With Particular Emphasis on the Communes of the Polish People)]. In: J. Kulas (Ed.), Gromady Ludu Polskiego. Materiaty z sesji naukowej [Communes of the Polish People. Proceedings of the Scientific Session] (pp. 16-48). Warszawa: Akademia Nauk Społecznych PZPR.

Bensaid, D. (2010). Wywłaszczeni. Marks, własność i komunizm [Expropriated. Marx, Property and Communism]. Trans. by Z.M. Kowalewski. Warszawa: Instytut Wydawniczy Książka i Prasa.

Brock, P. (1954). Zeno Świętostawski, a Polish Foterunner of the Narodniki. „The American Slavic and East European Review". No. 4. (pp. 566-587).

Brock, P. (1977). Polish Revolutionary Populism: a Study in Agrarian Socialist Thought from the 1830s to the 1850s. Toronto - Buffalo: University of Toronto Press.

Ciołkosz, A., Ciołkosz, L. (1966). Zarys dziejów socjalizmu polskiego [Outline of the History of the Polish Socialism]. Vol. I. Londyn: Gryf Publications LTD.

Hobsbawm E.J. (1971). Primitive Rebels; Studies in Archaic Forms of Social Movement in the 19th and 20th Centuries. Manchester: Manchester University Press.

Jodko-Narkiewicz W. (1904). Historya i system socyalizmu utopijnego wśród emigracyi polskiej 1834-1846 r. [History and System of the Utopian Socialism Among the Polish Exiles 1834-1846]. In: W. Jodko-Narkiewicz, \& S. Dyksztajn, Polski socyalizm utopijny na emigracyi (dwie rozprawy) [The Polish Utopian Socialism in Exile (Two Studies)] (pp. 1-62 ). Kraków: Nakładem Spółki Nakładowej „Książka”.

Jordhem, H. (2012). Against Periodization: Koselleck's Theory of Multiple Temporalities. "History and Theory". No. 2 (6). pp. 151-171.

Kalembka, S. (1971). Wielka Emigracja. Polskie wychodźstwo polityczne w latach 1831-1862 [The Great Emigration. The Polish Political Emigration in the Years 1831-1862]. Warszawa: Wiedza Powszechna.

Koberdowa, I. (1989). Polska rewolucyjna myśl społeczna na tle myśli europejskiej w połowie XIX wieku [The Polish Revolutionary Social Thought Against the Background of the European Thought in the Half of the 19th Century]. In: J. Kulas (Ed.), Gromady Ludu Polskiego. Materiaty z sesji naukowej [Communes of the Polish People. Proceedings of the Scientific Session] (pp. 7-15 ). Warszawa: Akademia Nauk Społecznych PZPR.

Koselleck, R., Sebastian, J.F., \& Feuntes, J.F. (2006). Conceptual History, Memory and Identity: an Interview with Reinhart Koselleck. "Contributions To The History Of Concepts". No. 1. pp. 99-127.

Kuligowski, P. (2012). Sword of Christ. Christian inspirations of Polish socialism before the January Uprising. "Journal of Education, Culture and Society". No. 1. pp. 115-126.

Łukaszewicz, W. (1951). Wpływ masonerii, karbonaryzmu i Józefa Mazziniego na polską myśl rewolucyjna w latach poprzedzających Wiosne Ludów [The Influence of Freemasonry, Carbonarism and Giuseppe Mazzini on the Polish Revolutionary Thought in the Years Preceding the Spring of Nations]. In: H. Katz, W. Łukaszewicz, \& G. Missalowa (Eds.), Wiosna Ludów w Europie. Część druga - zagadnienia ideologiczne [The Spring of Nations. Part Two - Ideological Issues] (pp. 167-384). Vol. III. Warszawa: Państwowy Instytut Wydawniczy.

Marchlewicz, K. (2008). Wielka emigracja na Wyspach Brytyjskich (1831-1863) [The Great Emigration on the British Isles (1831-1863)]. Poznań: Instytut Historii UAM.

Missalowa, G. (1951). Francuski socjalizm utopijny i jego wptyw na polska myśl rewolucyjna w latach 1830 1848 [The French Utopian Socialism and its Influence on the Polish Revolutionary Thought in the Years 1830-1848]. In: H. Katz, W. Łukaszewicz, \& G. Missalowa (Eds.), Wiosna Ludów w Europie. Część druga - zagadnienia ideologiczne [The Spring of Nations. Part Two - Ideological Issues] (pp. 5-165). Vol. III. Warszawa: Państwowy Instytut Wydawniczy.

Najdowski, Z. (1989). Problem utopijności Gromad Ludu Polskiego w świetle oświeceniowej i romantycznej wizji sprawiedliwości spotecznej [The Problem of Utopianism of the Communes of the Polish People in the Light of the Enlightenment and the Romantic Vision of Social Justice]. In: J. Kulas (Ed.), Gromady Ludu Polskiego. Materiaty z sesji naukowej [Communes of the Polish People. Proceedings of the Scientific Session] (pp. 62-67) . Warszawa: Akademia Nauk Społecznych PZPR.

Richter, M. (1996). Appreciating a Contemporary Classic: The GeschichtlicheGrundbegriffe and Future Scholarship. In: M. Richter, \& H. Lehmann (Eds.), The Meaning of Historical Terms and Concepts. New Stud- 
ies on Begriffsgeschichte (pp. 7-19). Washington: GERMAN HISTORICAL INSTITUTE.

Trencsényi, B. (2004). Conceptual History and Political Languages: On the Central-European Adaptation of the Contextualist-Conceptualist Methodologies of Intellectual History. In: P. Roubal, \& V. Veber V. (Eds.), Prague Perspectives.Studies in Central and Eastern Europe (pp. 142-166). Prague: Klementinum.

Turowski, J. (1958). Utopia społeczna Ludwika Królikowskiego 1799-1878 [The Social Utopia of Ludwik Królikowski 1799-1878]. Warszawa: Instytut Wydawniczy PAX.

Sepkowski, A. (1997). Utopie polskiego romantyzmu. Światopoglad a działanie [The Utopias of Polish Romanticism. Worldview and Action]. Piotrków Trybunalski: Wydawnictwo filii kieleckiej WSP w Piotrkowie Trybunalskim.

Sikora, A. (1974). Gromady Ludu Polskiego [The Communes of the Polish People]. Warszawa: Wiedza Powszechna.

Szpotański, S. (1907). Lud Polski (z dziejów polskiej myśli socyalistycznej) [The Polish People (The History of Polish Socialist Thought)]. Lwów: Polskie Towarzystwo Nakładowe.

Temkinowa H. (1962). Gromady Ludu Polskiego (zarys ideologii) [The Communes of the Polish People (Outline of Ideology)]. Warszawa: Książka i Wiedza.

Zamoyski, A. (2015). Swięte Szaleństwo: Romantycy, patrioci, rewolucjoniści 1776-1871 [Holy Madness: Romantics, Patriots and Revolutionaries 1776-1871]. Trans. by Ronikier M. Kraków: Wydawnictwo Literackie. 